Biochem. Lett., Vol.7, PP 201-214 (2012)

\title{
ANGIOTENSIN CONVERTING ENZYME GENOTYPE PREVALENCE AMONG EGYPTIAN PRIMARY NEPHROTIC AND END STAGE RENAL DISEASES PATIENTS
}

\author{
Zahran F. ${ }^{\text {; }}$ El Gamal E ${ }^{2}$; Hamed S. ${ }^{2}$; Keshta \\ A.T. ${ }^{1}$; Hussien M. ${ }^{1}$ \\ ${ }^{1}$ Biochemistry Division, Dept. of Chemistry, Faculty of \\ Science, Zagazig University; ${ }^{2}$ Urology \& Nephrology \\ center, Mansoura University, Egypt
}

\begin{abstract}
ABSRACT
The Renin-Angiotensin system (RAS) is a key regulator of both blood pressure and kidney functions and their interaction. In such a situation, genetic variability in the genes of different components of $R A S$ is likely to contribute for its heterogeneous association in the renal disease patients. Angiotensin converting enzyme-1 (ACE-1) is an important component of $R A S$ which determines the vasoactive peptide Angiotensin-II. In the present study, we have investigated 103 end stage renal diseases (ESRD), 104 primary nephrotic (P.N) patients and 102 normal healthy controls from Mansoura city in Egypt to deduce the association between $A C E$ gene polymorphism and ESRD, P.N. The selected samples were assayed for genotyping of ACE I/D by (PCR) based DNA amplification using specific flanking primers. The results revealed that there was a significance distribution in DD genotype between ESRD and control group $(p<0.05)$, with risk value $(O R>1)$ which resulting in increasing the risk for ESRD. There was significance distribution in ID genotype between ESRD and control group ( $p<0.05)$, without disease risk (OR $<1)$. Based on these observations we conclude that $A C E$ DD
\end{abstract}


Angiotensin Converting Enzyme

genotype implicate a strong possible role in the in renal damage among Egyptians. The study will help in predetermining the timing, type and doses of therapy for ESRD patients.

\section{INTRODUCTION}

Angiotensin-converting enzyme (ACE) is one of the limiting enzymes in the renin-angiotensin-aldosterone system (RAAS). An elevated angiotensin II level causes deleterious effects on renal haemodynamics and induces the expression of different growth factors, leading to glomerulosclerosis ${ }^{(1)}$.ACE inhibitors and angiotensin receptor blockers reduce proteinuria in patients with nephrotic syndrome, ${ }^{(2)}$ stressing the role of the RAAS in the pathogenesis of nephritic syndrome. A polymorphism of the ACE gene, consisting of a 287-bp fragment within intron 16 defined by insertion (I) or deletion (D), has been shown toinfluence the circulating and cellular ACE concentration ${ }^{(\mathbf{3 , 4})}$.

The ACE gene I/D polymorphism is reportedly associated with the progression ofseveral renal diseases, including diabetic nephropathy, IgA nephropathy, autosomal dominant polycystic kidney disease, and graft failure in renal transplant recipients. The D allele has a dominant effect and is associated with higher plasma ACE and angiotensin II levels ${ }^{(5)}$. The ACE DD genotype is associated with increased circulating ACE levels, which are generally two times as high as those found for the II genotype; ID heterozygotes are associated with intermediate ACE levels ${ }^{(6)}$. The ACE gene I/D polymorphism are reportedly associated with the progression of several renal diseases, including diabetic nephropathy, IgA nephropathy, autosomal dominant polycystic kidney disease, and graft failure in renal transplant recipients. The D allele has a dominant effect and is associated with higher plasma ACE and angiotensin II levels.

Our study aims to determine the ACE I/D genotype distribution in adult primary nephrotic syndrome and end stage renal disease patients and evaluate its effect on clinical parameters. 


\section{MATERIALS \& METHODS \\ Patients and controls \\ Our subjects divided in to three different groups, 104 primary nephrotic patients, 58 males $(55.8 \%)$ and 46 females $(44.2 \%)$, and their age ranged from 19-46 years with a mean of $30.63 \pm 6.99$ years. 103 ESRD patients 63 males $(61.2 \%)$ and 40 females $(38.8 \%)$, and their age ranged from $19-55$ years with a mean of $38.99 \pm 8.2$ years. And, 102 unrelated healthy adults with no renal diseases as a control group; 59 males (57.8\%) and 43 females (42.2\%), and their age ranged from $20-45$ years with a mean of $27.89 \pm 5.39$ years.}

\section{Genotyping of the ACE gene I/D polymorphism}

Genomic DNA was extracted from $300 \mu \mathrm{l}$ of whole blood, DNA extraction kit (promega company, USA). I/D polymorphism of the ACE gene was determined according to the method of Rigat et al (3). The sequences of the sense and antisense primers were (5'-CTG GAG ACC ACT CCC ATC CTT TCT-3' and 5'-GAT GTG GCC ATC ACA TTC GTC AGA T-3'), respectively. PCR was performed in a final volume of $50 \mu \mathrm{l}$ that contained $25 \mu \mathrm{l}$ master mixes, $\approx 500 \mathrm{ng}$ of genomic DNA, 12.5 pmol of each primer and 5\% dimethylsulphoxide (DMSO). Amplification was performed using a Gene Amp PCR system G-storm. Samples were denatured for 1 minute at $94^{\circ} \mathrm{C}$ and then cycled 30 times through the following steps: 45 seconds at $94^{\circ} \mathrm{C}$, 1 minute at $62^{\circ} \mathrm{C}$, and 1 minute at $72^{\circ} \mathrm{C}$. PCR products were electrophoresed in $1.6 \%$ agarose gel and visualised directly with ethidium bromide staining. I allele was detected as a 490-bp band, and the D allele was detected as a 190-bp band (figure 1). 1st PCR was confirmed by using the second PCR (9). A second PCR amplification was performed for each DD type with a primer pair that recognizes an insertion-specific sequence (5'- TGG GAC CAC AGC GCC CGC CAC TAC-3'; 5'-TCG CCA GCC CTC CCA TGC CCA TAA-3'), with identical PCR conditions except for an annealing temperature of $67^{\circ} \mathrm{C}$ and the absence of $5 \%$ DMSO (6).

\section{Biochemical parameters}




\section{Angiotensin Converting Enzyme}

Total cholesterol, Triglyceride \& LDL, Serum creatinine \& albumine were measured for all study population according to methods of; Young. (7); Stein,(8); Henry (9); Doumas et al.(10); respectively.

\section{Statistical analysis:}

The allele distribution of the ACE gene I/D polymorphism was tested for Hardy-Weinberg equilibrium in patient and control groups. A computer software package (SPSS), version 14 (11), was used in the analysis. For quantitative variables, mean and median (as a measure of central tendency), standard deviation. Frequency and percentage are presented for qualitative variables. Chi square test used to estimate differences in qualitative variables. $\mathrm{P}$ value $<0.05$ was considered to be statistically significant.

\section{RESULTS}

The genotype frequencies 1st PCR (II, ID and DD-genotypes) in nephrotic group were 10, 43 and 51; respectively. In addition the incidences of II, ID and DD in ESRD group were 0, 21 and 82; respectively. Where, in control group the incidences of II, ID and DD were 12, 66 and 24; respectively. The genotype frequencies 2nd PCR (II, ID and DD-genotypes) in nephrotic group were 10, 66 and 28; respectively. In addition the incidences of II, ID and DD in ESRD were 0,45 and 58; respectively. Where, in control group the incidences of II, ID and DD were 12, 74 and 16 respectively.

There was a significance in distribution in DD genotype between primary nephrotic and control group $(\mathrm{p}=0.049)$, with risk value equal $1.98>1$ which resulting in increasing the risk for disease. While there was non significance distribution in both ID \& II genotype between both P.N and control group ( $\mathrm{p}>0.05)$, without disease $\operatorname{risk}(\mathrm{OR}<1)$.

There was a significance in distribution in DD genotype between ESRD and control group $(p=0.000)$, with risk value equal $6.92>1$ which resulting in increasing the risk for ESRD. There was significance distribution in ID genotype between ESRD and control group $(\mathrm{p}=0.000)$, without disease risk $(\mathrm{OR}<1)$. 
Zahran F. et al.

Table (1) represents Chi-Square Test I/D allele in ESRD, P.N and control groups

\begin{tabular}{|r|c|c|c|c|c|c|}
\hline gemotype & II & ID & DD & I allele & D allele & p-value \\
groups & & & & & & \\
\hline control & 12 & 74 & 16 & 98 & 106 & 0.172 \\
P.N & 10 & 66 & $\mathbf{2 8}$ & $\mathbf{8 6}$ & 122 & \\
\hline control & 12 & 74 & $\mathbf{1 6}$ & 98 & $\mathbf{1 0 6}$ & 0.000 \\
ESRD & 0 & 45 & $\mathbf{5 8}$ & $\mathbf{4 5}$ & $\mathbf{1 6 1}$ & \\
\hline
\end{tabular}

P value Chi-Square Test $<0.05$

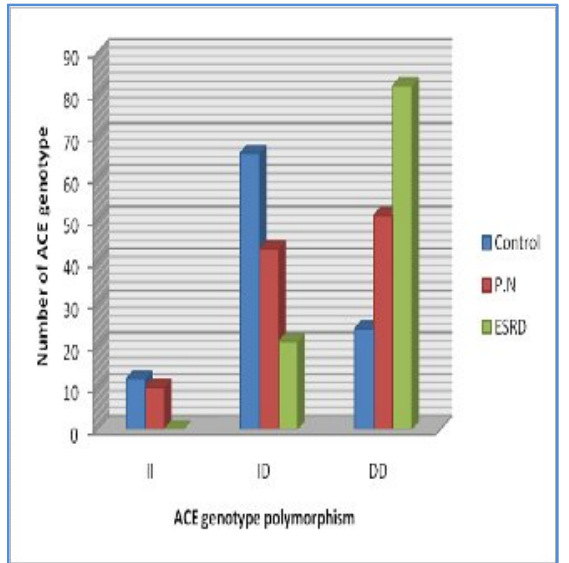

Fig (1) shows 1st PCR genotyping genotyping

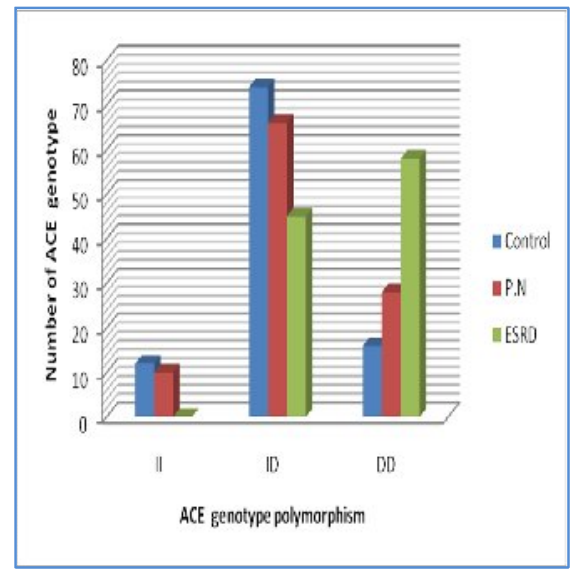

Fig (2) shows 2st PCR 


\section{Angiotensin Converting Enzyme}

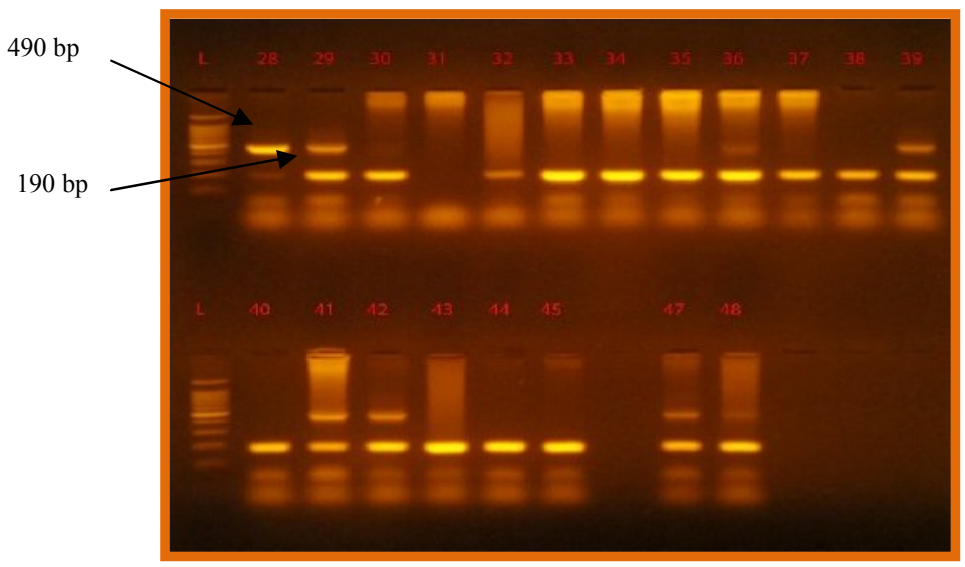

Figure (3): Agarose gel electrophoresis of 1st PCR products of ACE gene. Lines 29, 39, 41, 42, 47 heterozygous ID, 30, 32-38, 40, 43, 44, 45, 48 homozygous DD cases, 28 homozygous II cases. (I allele 490 bp, D allele 190 bp).

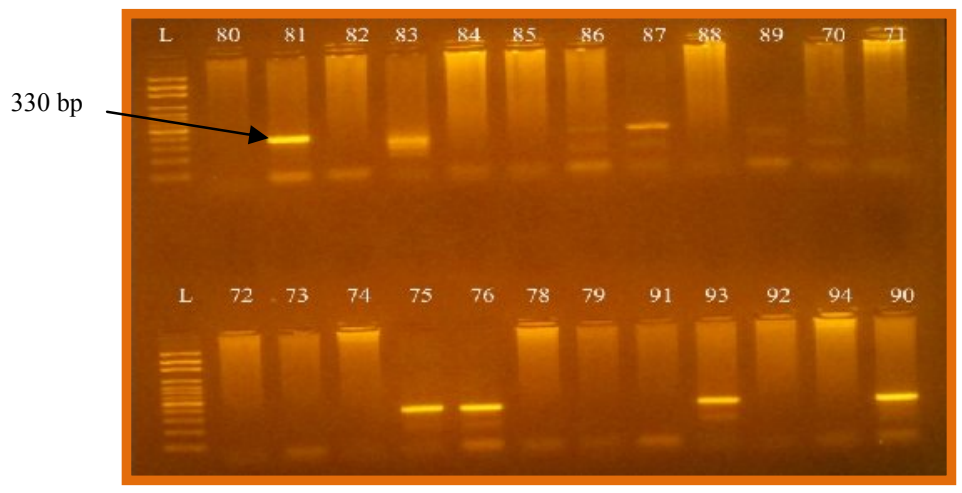

Figure (4): Agarose gel electrophoresis of $2^{\text {nd }}$ PCR products of ACE gene. Lines 81, $87,75,76,93,90$ heterozygous ID, the other Lines represent DD homozygous. (ID $330 \mathrm{bp})$ 
Zahran F. et al.

Table (2) represents Odds Ratio (OR) for ESRD, P.N and control groups.

\begin{tabular}{|c|c|c|c|c|c|c|}
\hline Alleles & Control & $\begin{array}{c}\text { Primary } \\
\text { Nephrotic }\end{array}$ & OR & $(95 \%$ CI) & Risk & $\begin{array}{c}\text { P-value for chi square } \\
\text { test }\end{array}$ \\
\hline D & 106 & 122 & 1.312 & $(0.889-1.93)$ & + & $P>0.05$ \\
\hline I & 98 & 86 & 0.762 & $(0.517-1.125)$ & - & $P>0.05$ \\
\hline Alleles & Control & ESRD & OR & $(95 \% \mathrm{CI})$ & Risk & $\begin{array}{c}\text { P-value for chi square } \\
\text { test }\end{array}$ \\
\hline D & 106 & 161 & 3.30 & $(2.15-5.08)$ & + & $P<0.05$ \\
\hline I & 98 & 45 & 0.302 & $(0.19-0.46)$ & - & $\mathrm{P}<0.05$ \\
\hline
\end{tabular}

P Chi-square Test $<0.05$ significant; $P$ OR $<1$ Risk disease; $P$ OR $>1$ Non Risk disease

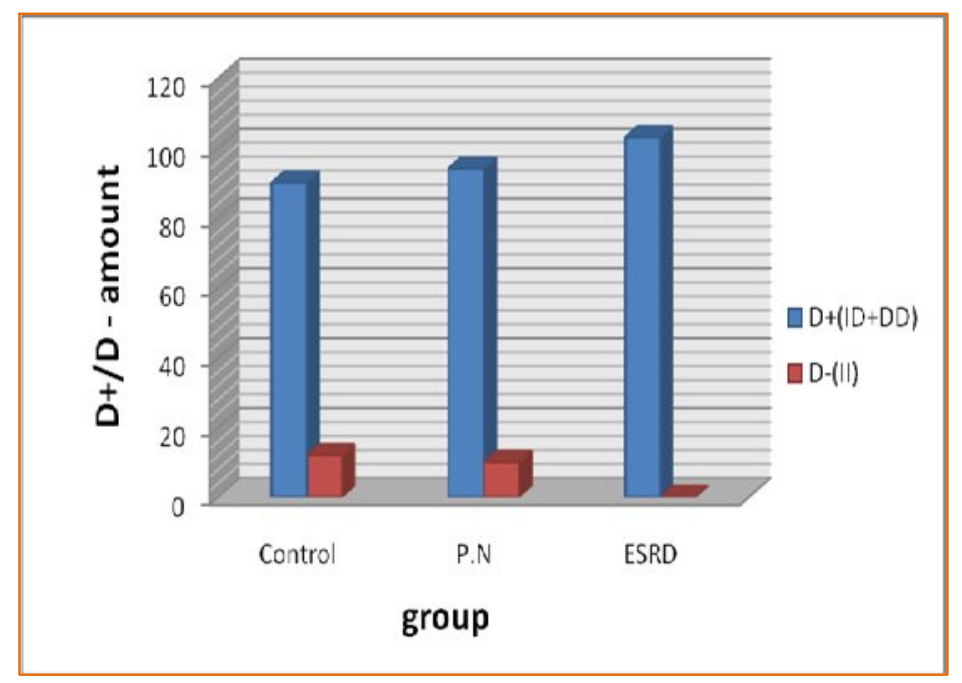




\section{Angiotensin Converting Enzyme}

Table (3) Prevalence of ACE I and D polymorphism genotype $1{ }^{\text {st }}$ PCR in patients and control groups.

\begin{tabular}{|r|c|c|c|c|}
\hline genotype & II & ID & DD & p-value \\
\hline groups & & & & \\
\hline Control & $\mathbf{1 2}$ & $\mathbf{6 6}$ & $\mathbf{2 4}$ & 0.001 \\
P.N & $\mathbf{1 0}$ & $\mathbf{4 3}$ & $\mathbf{5 1}$ & \\
\hline Control & $\mathbf{1 2}$ & $\mathbf{6 6}$ & $\mathbf{2 4}$ & 0.000 \\
ESRD & $\mathbf{0}$ & $\mathbf{2 1}$ & $\mathbf{8 2}$ & \\
\hline
\end{tabular}

P Chi-square Test $<0.05$ significant

Table (4) Prevalence of ACE I and D polymorphism genotype 2nd PCR in patients and control groups.

\begin{tabular}{|r|c|c|c|c|}
\hline genotype & II & ID & DD & p-value \\
\hline groups & & & & \\
\hline Control & $\mathbf{1 2}$ & $\mathbf{7 4}$ & $\mathbf{1 6}$ & 0.143 \\
P.N & $\mathbf{1 0}$ & $\mathbf{6 6}$ & $\mathbf{2 8}$ & \\
\hline Control & $\mathbf{1 2}$ & $\mathbf{7 4}$ & $\mathbf{1 6}$ & 0.000 \\
ESRD & $\mathbf{0}$ & $\mathbf{4 5}$ & $\mathbf{5 8}$ & \\
\hline
\end{tabular}


Zahran F. et al.

\section{P Chi-square Test $<0.05$ significant}

Table (5) Comparison of lipid profile,creatinin\& albumin in Control,P.N \& ESRD if ACE ID/DD.

\begin{tabular}{|c|c|c|c|c|c|}
\hline Group & $\begin{array}{c}\text { Cholesterol } \\
\text { mg/dL } \\
\text { mean } \pm \text { S.d }\end{array}$ & $\begin{array}{c}\text { T.glyceride } \\
\text { mg/dL } \\
\text { mean } \pm \text { S.d }\end{array}$ & $\begin{array}{c}\text { LDL } \\
\text { mg/dL } \\
\text { mean } \pm \text { S.d }\end{array}$ & $\begin{array}{c}\text { Creatinine } \\
\text { mg/dL } \\
\text { mean } \pm \text { S.d }\end{array}$ & $\begin{array}{c}\text { Albumine } \\
\text { g/dL } \\
\text { mean } \pm \text { S.d }\end{array}$ \\
\hline $\begin{array}{r}\text { Control } \\
\text { ID }\end{array}$ & $\begin{array}{l}170.75 \\
\pm 18.3\end{array}$ & $\begin{array}{l}70.09 \\
\pm 16.7\end{array}$ & $\begin{array}{c}73.3 \\
\pm 10.9\end{array}$ & $\begin{array}{c}0.95 \\
\pm 0.97\end{array}$ & $\begin{array}{c}4.19 \\
\pm 0.44\end{array}$ \\
\hline $\begin{array}{r}\text { Control } \\
\text { DD }\end{array}$ & $\begin{array}{c}171.3 \\
\pm 17.95\end{array}$ & $\begin{array}{r}73.25 \\
\pm 18.7\end{array}$ & $\begin{array}{c}70.8 \\
\pm 12.6\end{array}$ & $\begin{array}{c}1.3 \\
\pm 2.06\end{array}$ & $\begin{array}{c}3.99 \\
\pm 0.83\end{array}$ \\
\hline $\begin{array}{r}\text { P.Nephrotic } \\
\text { ID }\end{array}$ & $\begin{array}{c}220.12 \\
\pm 89.7\end{array}$ & $\begin{array}{c}176.2 \\
\pm 9.8\end{array}$ & $\begin{array}{l}99.64 \\
\pm 34.1\end{array}$ & $\begin{array}{c}2.6 \\
\pm 2.2\end{array}$ & $\begin{array}{c}3.13 \\
\pm 0.99\end{array}$ \\
\hline $\begin{array}{r}\text { P.Nephrotic } \\
\text { DD }\end{array}$ & $\begin{array}{r}228.4 \\
\pm 93.7\end{array}$ & $\begin{array}{r}174.5 \\
\pm 10.6\end{array}$ & $\begin{array}{l}112.0 \\
\pm 0.80\end{array}$ & $\begin{array}{l}3.10 \\
\pm 2.4\end{array}$ & $\begin{array}{c}3.1 \\
\pm 0.89\end{array}$ \\
\hline $\begin{array}{r}\text { ESRD } \\
\text { ID }\end{array}$ & $\begin{array}{c}234.76 \\
\pm 35.1\end{array}$ & $\begin{array}{l}248.9 \\
\pm 42.3\end{array}$ & $\begin{array}{l}150.5 \\
\pm 12.3\end{array}$ & $\begin{array}{l}10.49 \\
\pm 2.76\end{array}$ & $\begin{array}{c}3.02 \\
\pm 0.44\end{array}$ \\
\hline $\begin{array}{r}\text { ESRD } \\
\text { DD }\end{array}$ & $\begin{array}{l}236.45 \\
\pm 42.1\end{array}$ & $\begin{array}{c}256.4 \\
\pm 43.1\end{array}$ & $\begin{array}{l}149.7 \\
\pm 12.7\end{array}$ & $\begin{array}{l}10.71 \\
\pm 2.99\end{array}$ & $\begin{array}{c}3.03 \\
\pm 0.42\end{array}$ \\
\hline
\end{tabular}

\section{DISCUSSION}

The genetic origin of kidney diseases has been a focus of research in the past few years. There is significant evidence showing that the RAAS is involved in the pathogenesis of progressive renal disorders. As a matter of fact, in recent studies the association between disease progression and the ID/DD genotype of the ACE gene has been well described (2). Interestingly, it has been found that patients 


\section{Angiotensin Converting Enzyme}

with the DD genotype experienced a more severe clinical course (12). Angiotensin II is the most active product of the RAAS and it has a strong influence on local and systemic haemodynamic regulation.

Angiotensin II is also a renal growth factor that modulates key elements of renal disease progression, including renal mesangial cell growth, extracellular matrix synthesis, and degradation and inflammatory processes. The effects of angiotensin II are mediated by the release of several factors, including transforming growth factor-B (TGF-B), plasminogen activator inhibitor-1, monocyte chemoattractant protein-1, and the activation of various nuclear transcription factors, including activator protein-1 and nuclear factor kappa B (NF-kB) (13). The ACE DD genotype is associated with increased circulating ACE levels, which are generally two times as high as those found for the II genotype; ID heterozygotes are associated with intermediate ACE levels (6). A polymorphism of the ACE gene, consisting of a 287-base pair fragment within intron 16 defined by insertion (I) or deletion (D), has been shown to influence the circulating and cellular ACE concentration. The ACE gene I/D polymorphism are reportedly associated with the progression of several renal diseases, including diabetic nephropathy, IgA nephropathy, autosomal dominant polycystic kidney disease, and graft failure in renal transplant recipients. The D allele has a dominant effect and is associated with higher plasma ACE and angiotensin II levels.

In the current study, we tried to increase the specificity of ACE I/D genotyping by using DMSO in the first PCR. In addition, a second PCR was performed for the samples that showed DD genotype in the first step. Out of 51 patients with P.N syndrome showed initially the DD genotype, 23 patients were proven to have the ID. This was confirmed by the second PCR. Out of 82 patients with ESRD showed initially the DD genotype 24 patients were proven to have the ID genotype, also out of 24 control showed initially the DD genotype 8 control were proven to have the ID this was confirmed by using the second PCR.

The frequencies of the II, ID, and DD genotypes in controls were found to be 12,74 , and 16 , respectively, which statistically non 
significant compared to those of P.N and significant compared to ESRD patients. As a matter of fact, in recent studies the association between disease progression and the ID/DD genotype of the ACE gene has been well described by Bagga and Srivastava, (14).

This agrees with the study of Sasongko et al. ${ }^{(\mathbf{1 5})}$ who reported that the differences in the distribution of the ACE gene polymorphism between INS patients and controls were not statistically significant. This is, however, disagree with most other studies in which the DD genotype was significantly more common in nephrotic patients compared to normal individuals $(2,4$, and 16$)$.

Our study revealed a highly significant difference in the presence of DD genotype and D allele of ACE gene among ESRD patients and normal controls validating that the ACE gene polymorphism is an important genetic determinant of non-diabetic nephropathies. Overall findings were demarcating that $\mathrm{D}$ allele of $\mathrm{ACE}$ gene confers a high risk of developing renal diseases $(\mathbf{O R}=\mathbf{3 . 3 0})$ and this association was highly compounded when D allele was present in homozygous state $(\mathbf{O R}=\mathbf{6 . 9 2})$. Even inclusion of the heterozygous ID state known to have low levels of ACE production along with the DD genotype depicted a high risk of renal failures $(\mathbf{O R}=\mathbf{0 . 2 9})$. It has been found that patients with the DD genotype experienced a more severe clinical course Maha et al., (17). we confirmed our results by measuring different clinical parameters and their relation to polymorphism. ID polymorphism showed increase in cholesterol, triglyceride, LDL, and creatinin by $(29 \%, 151 \%, 35 \%, 188 \%)$ in P.N patients; while $(37 \%$, $254 \%, 105 \%, 105 \%)$ in ESRD compared to control. On the other hand; DD showed increase in cholesterol, triglyceride, LDL, and creatinin by $(33 \%, 275 \%, 60 \%, 20 \%)$ in P.N patients; while $(38 \%$, $250 \%, 112 \%, 723 \%$ ) in ESRD compared to control. Moreover, ID and DD polymorphism showed decrease in albumin by $25 \%$ and $23 \%$ in P.N and ESRD patients; respectively compared to control. Kidney disease is clinically characterized by increasing rates of urinary albumin excretion, starting from normoalbuminuria, which progresses to microalbuminuria, macroalbuminuria/overt nephropathy, and eventually to ESRD Choudhry et al., ${ }^{(\mathbf{1 8})}$. Therefore; ACE gene 


\section{Angiotensin Converting Enzyme}

polymorphism appears to be an important genetic determinant in causation and progression of renal diseases and ACE DD genotype was found to be strongly associated with ESRD.

\section{CONCULSION}

Conclusively, ACE gene polymorphism appears to be an important genetic determinant in progression of renal diseases and ACE DD genotype was found to be strongly associated with ESRD.

\section{ACKNOWLEDGEMENT}

The authors would like to thank members of Medical Experimental Research Center (MERC), Faculty of Medicine, Mansoura University for assistance.

\section{REFERENCES}

1.Oktem, F.; Sirin, A.; Bilge, I.; Emre, S.; Agachan, B.; Ispir, T., (2004): ACE I/D gene polymorphism in primary FSGS steroid-sensitive nephrotic syndrome. Pediatr Nephrol; 19:384-9.

2.White,CT.;Macpherson,CF.;Hurlet,RM.;Matsell,DG.(2003): Anti-iproteinuric effects of enalapril and losartan: a pilot study. Pediatr Nephrol; 18:1038-43.

3. Rigat, B.; Hubert, C.; Alhenc-Gelas, F.; Cambien, F.; Corvol, P.; Soubrier, F.(1990) An insertion/deletion polymorphism in the angiotensin I-converting enzyme gene accounting for half the variance of serum enzyme levels. J Clin Invest 1990; 86:1343-6.

\section{Costerousse, O.; Alledgrini, J.; Lopez, M., Alhenc-Gelas, F.} (1993): Angiotensin I converting enzyme in human 
circulating mononuclear cells: genetic polymorphism of expression in T-lymphocytes. Biochem J; 290:33-40.

5. Bagga, A.; Srivastava, RN. (2002): Nephrotic syndrome and proteinuria. Indian J Pediatr; 69:1053-4.

6. Ribichini, F.; Steffenino, G.; Dellavalle, A. (1998): Plasma activity and insertion/deletion polymorphism of angiotensin Iconverting enzyme, a major risk factor and a marker of risk for coronary stent restenosis. Circulation; 97:147-54.

7. Young DS., (2001): Effects of disease on Clinical Lab. Tests, $4^{\text {th }}$ ed. AACC.

8. Stein, EA., (1987): Lipids, lipoproteins, and apolipoproteins. In: Tietz NW, ed.Fundamentals of Clinical Chemistry. $3^{\text {rd }}$ ed. Philadelphia: WB Saunders 448-481.

9. Henry, RJ., (1974): Clinical chemistry. Principles and Techniques. Second Edition. Harper and row. P 525.

10. Doumas, BT., Watson, WA., and Biggs, HG., (1971): Albumin standards and the measurement of serum albumin with bromocresol green. Clin. Chim. 31: 87 - 96 .

11. Lvesque R.SPSS., (2007): programming and Data Management:aguid for SPSS and SAS users,Fourth . Edition,SPSS.inc.,ChicagoIII.

12. Frishberg, Y.; Becker-Cohen, R.; Halle, D., (1998): Genetic polymorphisms of the renin-angiotensin system the outcome of focal segmental glomerulosclerosis in children. Kidney Int; 54:1843-9.

13. Serdaroglu, E.; Mir, S.; Berdeli, A. (2005) ACE gene insertion/deletion polymorphism in childhood idiopathic nephrotic syndrome. Pediatr Nephrol; 20:1738-43. 


\section{Angiotensin Converting Enzyme}

14. Bagga A, and Srivastava RN., (2002): Nephrotic syndrome and proteinuria. Indian J Pediatr; 69:1053-4.

15. Sasongko, T.; Sadewa, AH.; Kusuma, PA.; et al. (2005): ACE gene polymorphism in children with nephrotic syndrome in the Indonesian population. Kobe J Med Sci; 51:41-7.

16. Al-Eisa, A.; Haider, MS.; Srivastava, BS. (2001): Angiotensin converting enzyme gene insertion/deletion polymorphism in idiopathic nephrotic syndrome in Kuwaiti Arab children. Scand J Urol Nephrol; 35:239-42.

17. Maha S.A., Samar S., Inas Abdel-L., Hanaa N., Soheir A.A. and Sanaa Abdel-S., (2010): Effect of angiotensinconverting enzyme gene insertion/deletion polymorphism on steroid resistance in Egyptian children with idiopathic nephrotic syndrome. Journal of the Renin-AngiotensinAldosteroneSystem. 11(2); 111-118.

18. Choudhry N., Nagra S.A., Shafi T., Mujtaba G., Abiodullah M. and Rashid N., (2012): Lack of association of insertion/deletion polymorphism in angiotensin converting enzyme gene with nephropathy in type 2 diabetic patients in Punjabi population of Pakistan. African Journal of Biotechnology. 11(6), pp. 1484-1489. 